\title{
A BURROW CAST WITH LYSTROSAURUS SKELETAL REMAINS FROM THE LOWER TRIASSIC OF SOUTH AFRICA
}

\author{
SEAN P. MODESTO ${ }^{1 *}$ and JENNIFER BOTHA-BRINK ${ }^{2}$ \\ ${ }^{1}$ Department of Biology, Cape Breton University, Sydney, Nova Scotia, B1P 6L2, Canada; \\ ${ }^{2}$ Department of Karoo Palaeontology, National Museum, Bloemfontein, 9300 and Department of Zoology and Entomology, University of the Free State, \\ Bloemfontein, 9300, South Africa \\ e-mail:sean_modesto@cbu.ca
}

\begin{abstract}
We report on a large burrow cast with skeletal contents from Lower Triassic strata of the Palingkloof Member of the Balfour Formation, which forms the lowermost portion of the Lystrosaurus Assemblage Zone (LAZ) of South Africa. The burrow cast is similar to large burrow casts previously described from the LAZ that were identified as large-scale Scoyenia domichnia. It is the first large burrow cast from the LAZ found to contain diagnostic fossil bone. The burrow cast is a relatively straight, subhorizontal (inclined $\sim 12^{\circ}$ ), dorsoventrally compressed tube consisting of an entry ramp and living chamber; the entrance to the burrow is not preserved and there is no evidence that the ramp formed a spiral section. The skeletal material comprises a single, partial, disarticulated skeleton of a juvenile animal that can be assigned with confidence to the dicynodont genus Lystrosaurus. Whereas similar large-diameter burrow casts from strata slightly higher in the LAZ have been attributed to Lystrosaurus, we present an alternative hypothesis that a carnivorous tetrapod constructed the burrow. Our preferred hypothesis is supported by the observation that the interred Lystrosaurus skeleton is too small to be the maker of this particular burrow, by the general observation that carnivorous tetrapods construct relatively straight burrows, and by the partial, disarticulated state of the skeleton, which we interpret as the remains of larded prey. We suggest that akidnognathid theriodonts of the genera Moschorhinus or Olivierosuchus, the most conspicuous large predators of the LAZ, were the constructors of large-diameter, subhorizontal burrows.
\end{abstract}

\section{INTRODUCTION}

Lower Triassic rocks of South Africa record a diverse ichnofauna of vertebrate and invertebrate burrows and the possible remains of other forms of shelter burrows (Groenewald, 1991; Damiani et al., 2003; Abdala et al., 2006; Gastaldo and Rolerson, 2008). Some of the largest burrow casts have been attributed to species of the dicynodont synapsid genus Lystrosaurus, the most numerous, large vertebrate taxon present in the Induan-Olenekian Lystrosaurus Assemblage Zone (LAZ). Groenewald (1991) described large, single burrows $(20-45 \mathrm{~cm}$ in diameter and up to $100 \mathrm{~cm}$ long; burrow type " $1 \mathrm{~b}$ " according to his table 2) that he regarded as assignable to the ichnogenus Scoyenia. Two of the alleged Lystrosaurus burrow casts documented by Groenewald (1991) contained bone fragments, but these were either undiagnosable or (at the time) awaiting formal taxonomic identification. The burrow casts mentioned by Retallack et al. (2003) were large structures attributed to the ichnogenus Histioderma and contained remains that they referred to Lystrosaurus. Retallack et al. (2003), however, provided neither illustrations nor descriptions of the body fossils.

Identifications of dicynodonts of the genus Lystrosaurus as the tracemakers (or occupants) of large burrow casts in the rocks of the LAZ, such as those by Groenewald (1991) and Retallack et al. (2003),

* Corresponding author.

Copyright $\odot$ 2010, SEPM (Society for Sedimentary Geology) are based on circumstantial evidence: fossils of Lystrosaurus are the most commonly encountered vertebrates in the LAZ, and most Lystrosaurus skeletons are of the appropriate size to have occupied large burrows. The lack of documentation that would confirm individuals of Lystrosaurus as the tracemakers of the large burrow casts is regrettable because it precludes independent assessment of the taxonomic affinities of the associated skeletons. This oversight is important because the LAZ includes other large tetrapods-the archosauriform reptile Proterosuchus fergusi and the theriodont synapsids Moschorhinus kitchingi and Olivierosuchus parringtoni-that, despite being less common members of the LAZ, are potential alternative candidates for burrow constructors.

Recent prospecting of LAZ rocks in the vicinity of Middelburg, Eastern Cape Province, South Africa (Fig. 1), resulted in the discovery of a large burrow cast that entombs skeletal remains. This burrow cast resembles structures from the Katberg Formation that were described by Groenewald (1991, p. 21) and classified by him as large-scale Scoyenia domichnia (dwelling burrows). As those burrow casts lack surficial ornamentation consisting of longitudinal striations, one of the diagnostic characters of the ichnogenus Scoyenia (Frey et al., 1984), we henceforth refer to these large-diameter, subhorizontal burrows as type 1b burrow casts, following Groenewald's (1991, table 2) informal designation. The new burrow cast was found on the Middelburg district farm Barendskraal, which preserves a relatively rich LAZ fauna that includes Lystrosaurus spp., M. kitchingi, P. fergusi, and several smaller synapsid and reptilian taxa (Damiani et al., 2004). Thus, all large LAZ faunal elements that are potential makers of large burrows are present at Barendskraal. We prepared the living chamber of the burrow cast to exhume the skeletal remains and to examine the evidence for the hypothesis that large burrow casts from the Lystrosaurus AZ are attributable to dicynodonts of the genus Lystrosaurus.

\section{MATERIAL AND METHODS}

The burrow cast described here has been accessioned into the collections of the National Museum, Bloemfontein as NMQR 3606. The burrow terminus - interpreted as the living chamber - and adjoining section of the ramp were collected by us in 2007 from $\sim 30 \mathrm{~m}$ from the base of Maanhaar hill on the farm Barendskraal (Fig. 2). The burrow cast is positioned stratigraphically $2 \mathrm{~m}$ below the lowermost sandstone assigned to the Katberg Formation on Barendskraal, and, thus, NMQR 3606 comes from the uppermost strata of the argillaceous Palingkloof Member of the Balfour Formation (Fig. 3).

Skeletal remains collected from Maanhaar have been assigned to Lystrosaurus sp., the procolophonoids Owenetta kitchingorum, Saurodektes rogersorum, Procolophonoidea indet., and small baurioid therocephalians (Damiani et al., 2004), whereas those referred to Moschorhinus kitchingi and Proterosuchus fergusi were collected from exposures elsewhere on the farm (Agterkamp) in 2001 and 2002 


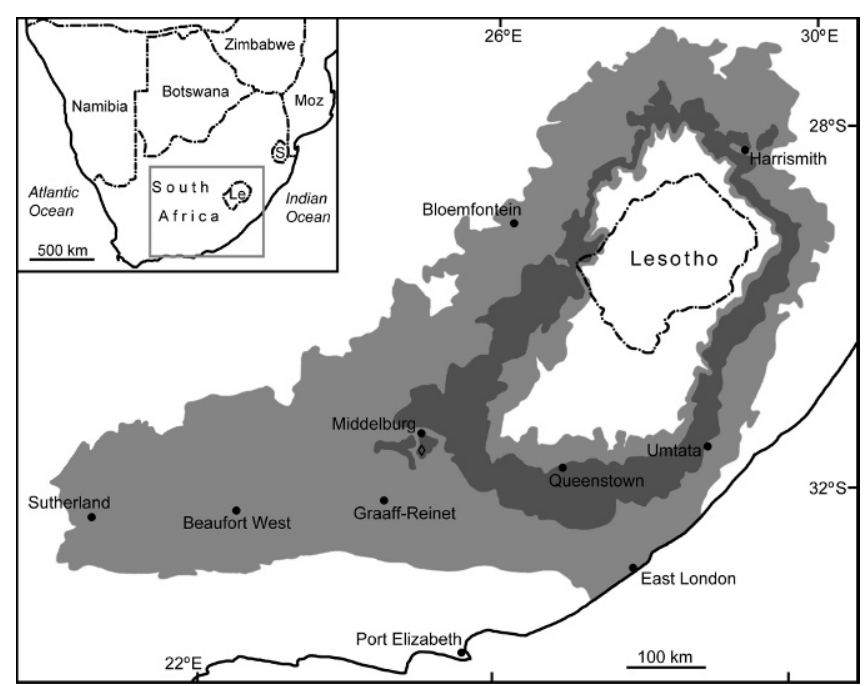

FIGURE 1-Geographic location of the Middelburg district farm Barendskraal (open diamond) in southeastern South Africa. Light gray shading indicates Beaufort Group exposures exclusive of Lystrosaurus Assemblage Zone rocks (dark gray shading). Main map redrawn from Groenewald and Kitching (1995); inset map redrawn from Groenewald (1991). Abbreviations (inset map): Le $=$ Lesotho, $\mathrm{Moz}=$ Mozambique, $\mathrm{S}=$ Swaziland.

(Damiani et al., 2004). To this faunal list we are able to add the theriodont Olivierosuchus parringtoni, following our collection in 2007 of a partial theriodont skeleton that we refer to this species (BothaBrink and Modesto, unpublished data, 2010).

The collected portions of the burrow cast were prepared mechanically, with a pneumatic airscribe, from the upper surface downwards in the expectation of revealing an articulated skeleton in dorsal aspect. The upper surfaces-although not necessarily the anatomical dorsal surfaces - of the skeletal contents were exposed after the approximate upper $75 \%-80 \%$ of the burrow cast was removed. The skeletal elements were then photographed, and the diagnostic elements were illustrated as specimen drawings.

\section{DESCRIPTION}

The burrow fill consists of the same gray mudstone that surrounds the burrow cast (Fig. 4). The burrow ramp descends at an angle of $\sim 12^{\circ}$ with respect to the surrounding strata and then levels out for the final $\sim 25 \mathrm{~cm}$ forming the living chamber. The burrow cast is flattened slightly by lithostatic compression, and a layer of sandy mudstone truncates the top of the ramp portion of the burrow cast. No obvious scratch marks were in evidence (Fig. 5). The cross section through the living chamber was (prior to preparation) $\sim 12 \mathrm{~cm}$ tall and $34 \mathrm{~cm}$ wide. The collected portions of the burrow cast have been reduced to $2-3 \mathrm{~cm}$ thick in the course of preparation undertaken to expose the skeletal contents.

Body fossils consist of disarticulated cranial and postcranial elements (Fig. 6). The bones are well preserved and exhibit no weathering or signs of scavenging, although there is peculiar damage to a single element (a scapula). The recognizable cranial elements consist of a premaxilla and a maxilla. The former element, preserved ventral side up at the end of the living chamber, is characterized by a tall, slightly convex anterior surface that meets both lateral surfaces along rounded, anterodorsally aligned corners, terminating ventrally with a U-shaped palatal rim (Figs. 7A-B). Parallel, paired anterior palatal ridges and a single, median posterior palatal ridge are well exposed on the palatal portion of the bone. The strongly developed, ventrally extended premaxilla is diagnostic of the genus Lystrosaurus. It has an extensive facial portion, which distinguishes it from other dicynodonts (Cluver,

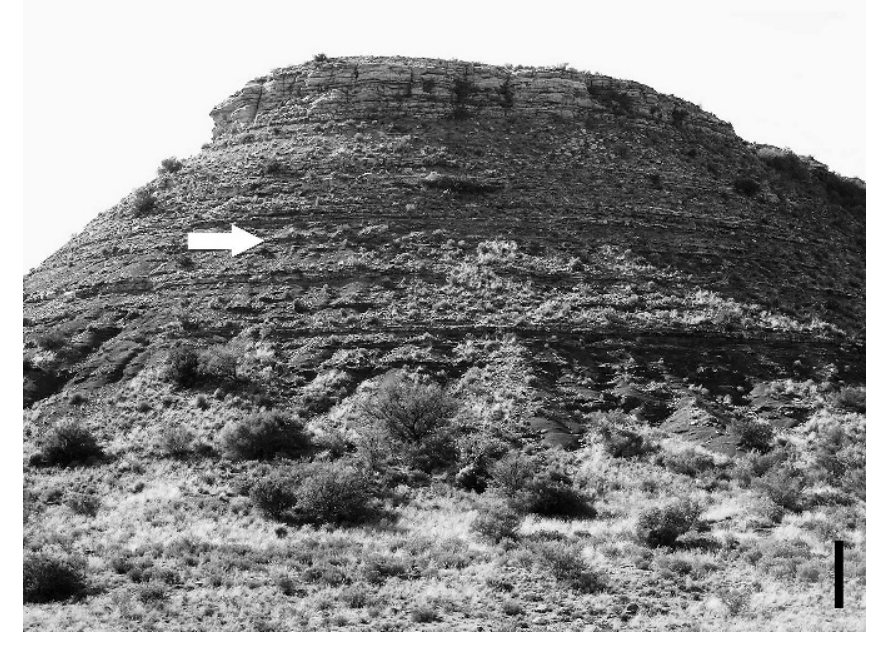

FIGURE 2-Photograph of Maanhaar hill on the Middelburg farm Barendskraal, showing outcrop of the Lower Triassic Lystrosaurus Assemblage Zone, with position of burrow (NMQR 3606) indicated by arrow. Scale bar $10 \mathrm{~m}$.

1971). The maxilla (Figs. 7C-D) is a left element preserved at the bottom of the entry ramp ( $\sim 35 \mathrm{~cm}$ from the premaxilla). It is complementary to the premaxilla in size. Exposed in lateral aspect, it is a quadrangular element in outline, with a distinct palatal rim, a weakly sigmoidal anterodorsal margin for contact with the premaxilla and shallow embayment for the external naris, a weakly concave dorsal margin for contact with the nasal and the lacrimal, posterior process for underlying the jugal, and slightly sigmoidal posteroventral margin forming the anterior part of the ventral margin of the skull roof. The posteroventral region is moderately swollen for the tusk, which is preserved as a stump.

There are $\sim 32$ postcranial bones and 8 unidentifiable bone fragments strewn across the floor of the living chamber and the base of the ramp. Two of these elements, a left scapula and a right ilium, allow confident assignment to Lystrosaurus. None of the remaining postcranial bones exhibit diagnostic features that would contradict the taxonomic assignment to the genus Lystrosaurus. Remarkably, only three vertebral elements are exposed. These consist of three centra; the lack of neural arches fused to these centra indicates an ontogenetically young age. Ten appendicular elements are present, among which the most informative are the scapula and the ilium. The extensive anteroposterior expansion-described as widely flaring by Ray (2006, table 1) - of the scapular blade (Figs. 7E-F) is a diagnostic feature of the genus Lystrosaurus. Ray (2006, table 1) also describes the scapula of Lystrosaurus as being distinguished by a thickened caudal margin, but this is not evident in our specimen. The absence of such thickening may be attributed to the immaturity (small size) of the skeleton: the scapula of NMQR 3606 is 33\% the height of a scapula from a presumed adult Lystrosaurus that was described and illustrated by Ray (2006, fig. 2a). The scapula (Figs. 7E-F) is interesting from a taphonomic perspective in exhibiting a conspicuous emargination that is $\sim 15 \mathrm{~mm}$ deep (anteroposteriorly) and $17 \mathrm{~mm}$ wide (dorsoventrally).

Two deep, rounded notches in the posterodorsal margin of the iliac blade are the most distinctive features of the ilium (Figs. $7 \mathrm{G}-\mathrm{H}$ ). Among therapsids, iliac notches have been documented only in the genus Lystrosaurus (Watson, 1912; Ray, 2006). The ilium is exposed in medial aspect, revealing an extensively roughened surface for the attachment of the sacral ribs. The remaining appendicular elements comprise limb bones, including both clavicles, a coracoid, a humerus, a femur, and several epipodial elements. The ends of pro- and epipodials are not finished in periosteal bone, which is additional evidence of the ontogenetically young age of the skeleton. Like the cranial elements, the ilium and the other large appendicular bones are positioned $\leq 10 \mathrm{~cm}$ 


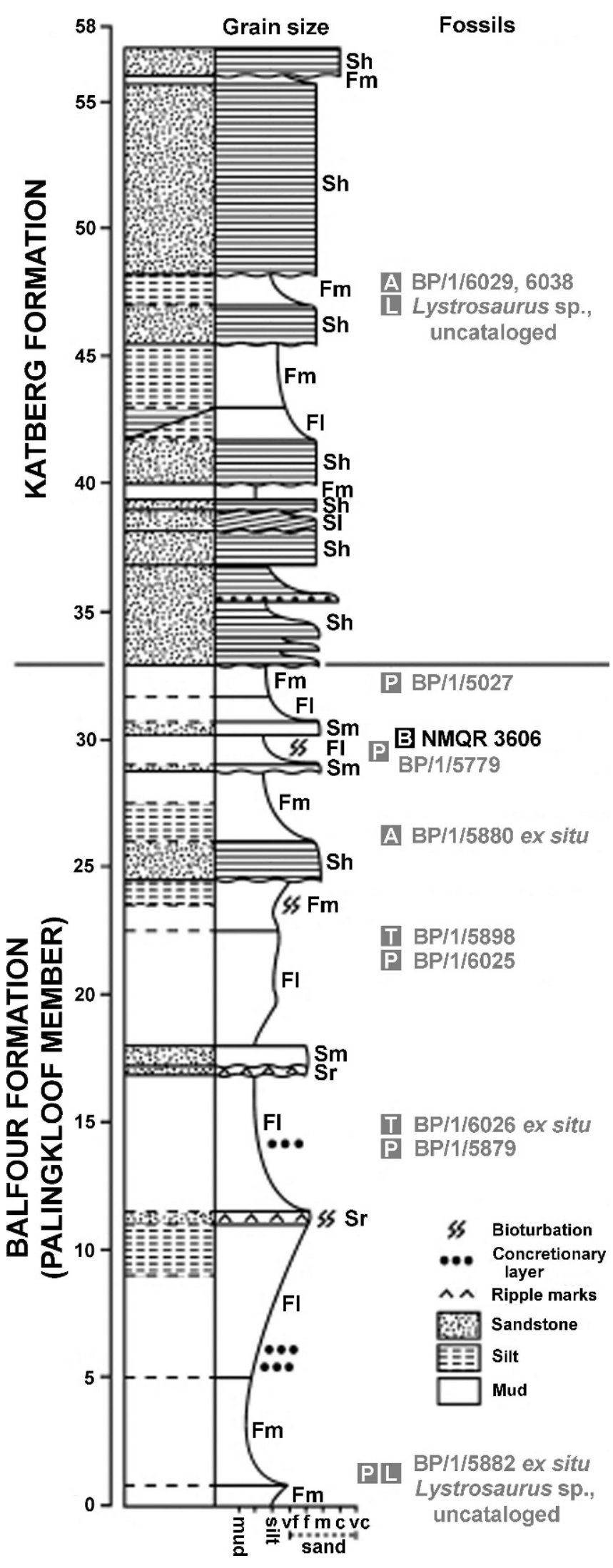

FIGURE 3-Stratigraphic position of NMQR 3606 at Barendskraal, Lystrosaurus Assemblage Zone, South Africa. Sedimentological log modified from Damiani et al. (2004, fig. 1), used with permission of Johann Neveling. Previous fossil discoveries in gray. Scale in meters. Key to facies (from Damiani et al., 2004): Fl = finely laminated sand, silt, and mud, Fm = massive fines (mudstone, siltstone), $\mathrm{Sh}=$ horizontally laminated sandstone, $\mathrm{Sl}=$ low-angle cross-bedded sandstone, $\mathrm{Sm}=$ massive from the former walls of the burrow; ribs and other small elements are distributed haphazardly over the floor of the burrow.

\section{DISCUSSION}

NMQR 3606 represents the first burrow cast from the Lystrosaurus Assemblage Zone (LAZ) in which the recovered skeletal remains can be assigned confidently to the dicynodont genus Lystrosaurus. Previous attributions of skeletal contents from large burrows to this genus by previous workers (Groenewald, 1991; Retallack et al., 2003) were published in papers in which the body fossils were mentioned as present, but were not documented by anatomical descriptions and illustrations, nor were the remains catalogued into museum collections, thereby precluding independent taxonomic reassessment.

The burrow cast closely resembles large-diameter, subhorizontal burrow casts described by Groenewald (1991, table 2, his type 1b) in overall organization (single large burrow, no apparent coiling), approximate dimensions (diameter falls within range of $20-45 \mathrm{~cm}$ ), and ramp angle $\left(\sim 12^{\circ}\right.$; close to $1^{\circ}-10^{\circ}$, versus $40^{\circ}$ for Histioderma domichnia, also attributed to Lystrosaurus: Groenewald, 1991). NMQR 3606 differs from Groenewald's (1991, table 2) description of large burrow casts in that there are no associated burrows (i.e., no burrows of same type overlying at right angles), no association with casts of desiccation cracks, and burrow fill is the same mudstone as host rockas opposed to sandstone burrow cast in mudstone host rock. The final difference is that the burrow casts described by Groenewald (1991, p. 20) contained no skeletal remains. These minor discrepancies can be attributed to individual behaviors of the burrow makers, which account for lack of overlying burrows and the lack of skeletal remains; paleoenvironmental differences, which account for absence of casts of desiccation cracks; and available fill sediment in the paleoenvironment, because the Palingkloof Member is dominated by mudstones (Smith and Botha, 2005), as opposed to predominant sandstones of the Katberg Formation on the farms studied by Groenewald (1991). In its subhorizontal attitude and its general morphology NMQR 3606 resembles Miocene burrow casts assigned to the ichnogenus Katarrhedites Hembree and Hasiotis, 2008, but differs in that the terminal chamber is not enlarged. Considering that NMQR 3606 is not complete (the entrance was not preserved) and that we have not had an opportunity to examine Groenewald's (1991) type 1b burrow casts and make detailed comparisons, we choose not to assign NMQR 3606 to an ichnotaxon at this time.

The morphology of the premaxilla, the scapula, and the ilium indicate that the skeleton can be assigned with confidence to the dicynodont genus Lystrosaurus. Although taxonomic assignment to species level is not possible with the available skeletal remains, the only species of Lystrosaurus that are known from the uppermost strata of the Palingkloof Member are L. murrayi and L. declivis (Botha and Smith, 2007), so it seems likely that NMQR 3606 represents one or the other. The disarticulation and the distribution of the skeletal elements indicate that the skeleton was disturbed prior to burial. A nonrandom pattern is suggested by the separation of formerly closely associated elements, and the positioning of the large cranial elements and the larger appendicular bones, along the periphery of the floor of the resting chamber. In contrast, the ribs and relatively flat limb bones (e.g., a radius) are distributed more or less randomly across the floor of the living chamber. This distribution of the skeletal elements of differing sizes in NMQR 3606 does not seem to be consonant with taphonomic interpretations of

$\leftarrow$

sandstone, $\mathrm{Sr}=$ ripple cross-laminated sandstone. Key to fossils (closed boxes): $\mathrm{A}=$ Archosauromorpha (Prolacerta), $\mathrm{B}=$ burrow cast, $\mathrm{L}=$ Lystrosaurus, $\mathrm{P}=$ Procolophonoidea, $\mathrm{T}=$ Therocephalia. Institutional abbreviation: $\mathrm{BP}=$ Bernard Price Institute for Palaeontological Research, University of the Witwatersrand, Johannesburg. 


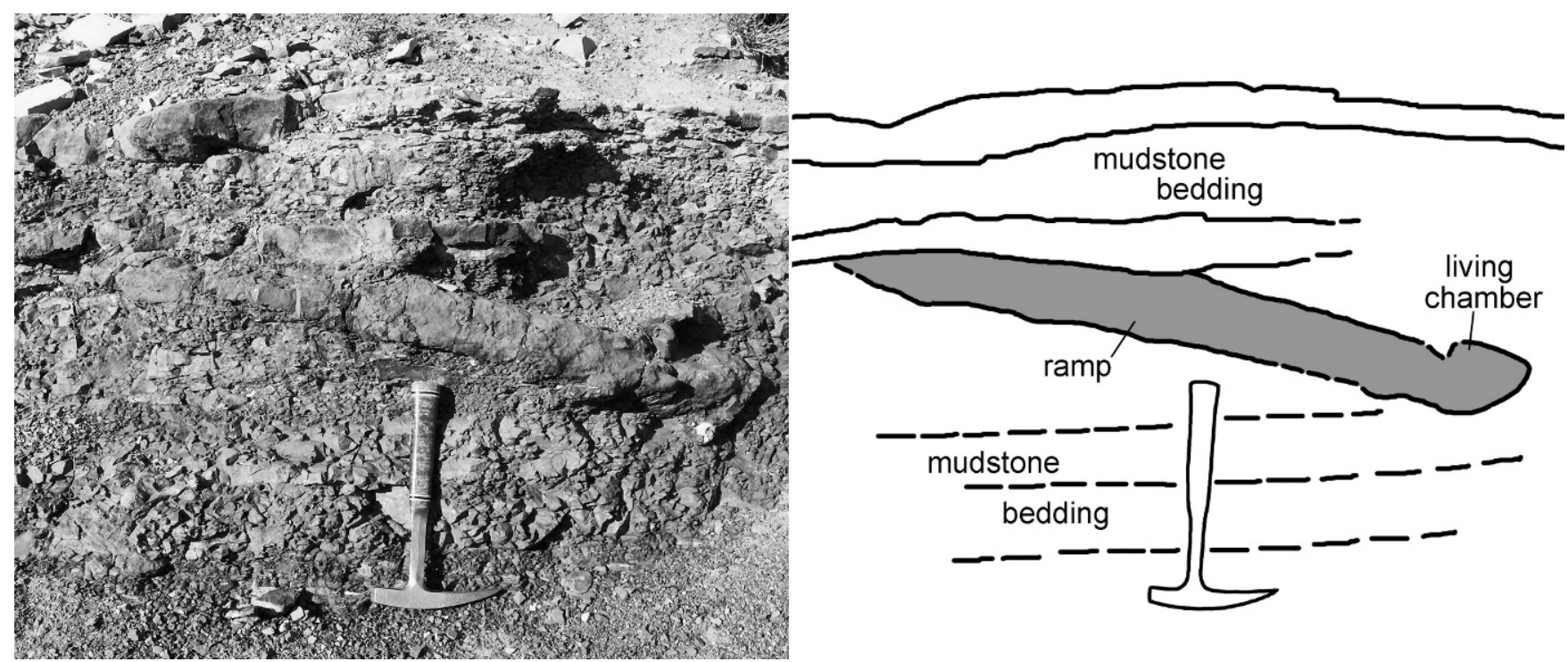

FIGURE 4-Photograph and interpretive sketch of burrow cast as found on the hillside of Maanhaar on Barendskraal. Burrow cast in gray in sketch. Rock hammer $31 \mathrm{~cm}$ long.

water-mediated (fluvial) distribution of vertebrate bones (e.g., Weigelt, 1989), although it is possible that rapid flooding of the burrow may have disarticulated and rearranged the bones. Such a scenario, however, does not account for the absence of most of the skull and over half of the postcranial skeleton. Alternatively, the preserved distribution of the disarticulated elements is suggestive of animal-mediated repositioning: a relatively large animal may have occupied the burrow after the

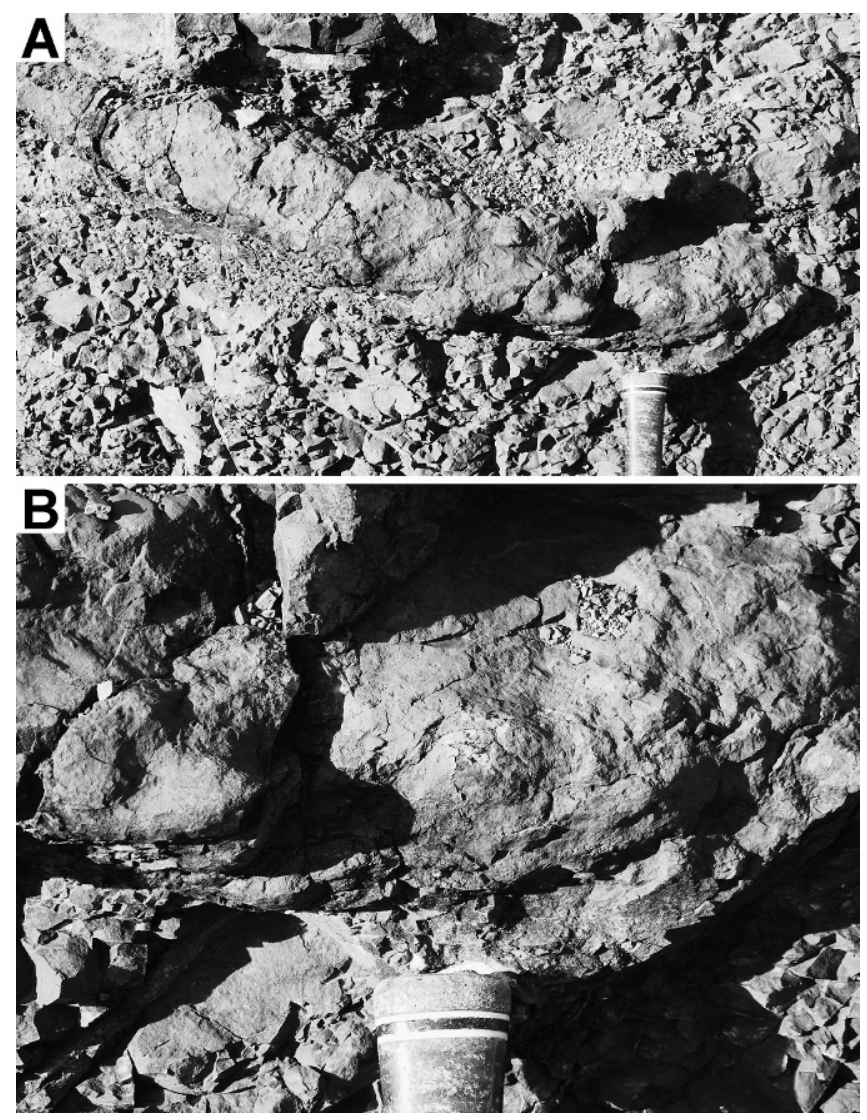

FIGURE 5-Photographs of in situ burrow cast showing surface details of (A) ramp and terminal chamber and (B) close up of terminal chamber. Hammer handle $51 \mathrm{~mm}$ wide.
Lystrosaurus carcass had become skeletonized. This occupant could have pushed the largest Lystrosaurus elements to the periphery of the living chamber, and concomitantly pressed the ribs, relatively flat bones, and small elements (e.g., vertebral centra) into the floor of the burrow. The latter possibility would have been facilitated if some sediment had accumulated after the Lystrosaurus individual had been skeletonized but prior to re-occupation. The putative subsequent occupant, or perhaps it was the original burrow constructor, may have also removed some or all of the elements that are missing from NMQR 3606. Secondary occupation of burrows is not uncommon among recent fauna (Kinlaw, 1999). For example, extant reptiles and other tetrapods readily move into burrows made by other species (Hoogland, 1995; Kerr and Bull, 2004; White and Cameron, 2009), sometimes even when the original tracemaker is still present (Taber, 1945; Witz et al., 1991).

As this is the first large burrow cast discovered to contain skeletal contents, it represents an apt test of Groenewald's (1991) hypothesis that Lystrosaurus constructed these types of burrows. The appendicular morphology of the genus Lystrosaurus is well known, and those who have considered the functional significance of the limbs (e.g., King and Cluver, 1991; Ray, 2006) consider that members of Lystrosaurus were well adapted for a burrowing lifestyle. Further support for the hypothesis of burrowing for Lystrosaurus comes from the observation that these types of burrow casts are not uncommon ichnological structures of vertebrate origin in the LAZ (at least three localities: Groenewald, 1991; this study). It seems reasonable, therefore, to attribute large burrow casts to Lystrosaurus because this genus is the most common faunal element of LAZ, comprising up to $95 \%$ of the fossils (Groenewald and Kitching, 1995).

Evidence that fails to support the hypothesis that NMQR 3606 was constructed by an individual of Lystrosaurus is that the burrow is of a size greater than expected to have been constructed by an individual the size of the interred juvenile Lystrosaurus. The size of the preserved cranial elements suggests a skull that was $\leq 10 \mathrm{~cm}$ broad, which would seem too small for the entry tunnel, which we estimate to have been $\geq 30 \mathrm{~cm}$. It is generally held that most burrowing tetrapods construct the tunnel portions of their burrows to be only as large as needed to fit their bodies (Voorhies, 1975; White, 2005; Gobetz, 2006). Thus, NMQR 3606 appears to be too large for the interred Lystrosaurus. A minority interpretation was offered by Groenewald et al. (2001), who proposed that the relatively wide and longitudinally ridged-bottomed burrow tunnels of the Middle Triassic cynodont genus Trirachodon were attributable to two-way traffic, an idea that is plausible given the 


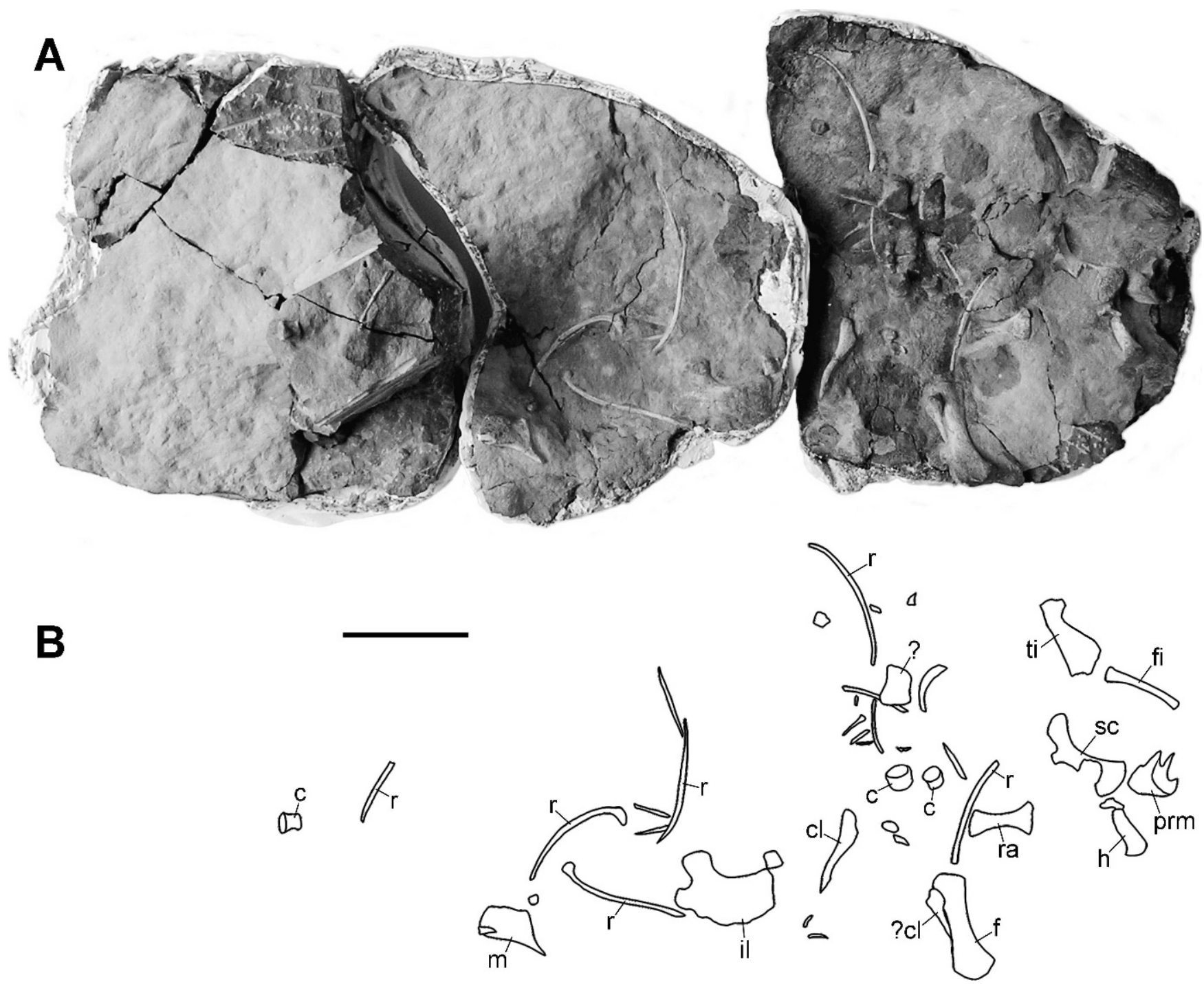

FIGURE 6-Top view of the prepared living chamber and lowermost section of the ramp of burrow cast NMQR 3606 (A) and bone outlines (B). Burrow entrance is to the left Abbreviations: $\mathrm{c}=$ centrum, $\mathrm{cl}=$ clavicle, $\mathrm{f}=$ femur, $\mathrm{fi}=$ fibula, $\mathrm{h}=$ humerus, $\mathrm{il}=$ ilium, $\mathrm{m}=$ maxilla; prm $=$ premaxilla, $\mathrm{r}=$ rib, $\mathrm{ra}=$ radius, $\mathrm{sc}=\mathrm{scapula}$, ti $=$ tibia. $\mathrm{Scale}$ bar $10 \mathrm{~cm}$.

apparent colonial nature of the tracemakers; Hasiotis et al. (2004), however, have documented in extant and fossil burrows that the central furrow in burrows is produced by one individual large enough to straddle the ridge as it excavated and traveled through the burrow. The observation that NMQR 3606 is the only burrow known from Barendskraal, however, argues against the tracemaker as a member of a colonial or gregarious species, and we conclude that it is unlikely that our burrow cast was constructed and occupied by more than a single individual. The lack of identifiable scratch marks could mean that the burrow was relatively old by the time the remains were deposited in the terminal chamber (and the infilling of the burrow): the tracemaker of this burrow could have erased surficial markings with general use. This interpretation is compatible with the idea that burrowers generally do not dig tunnels with diameters much greater than will admit their own bodies. Accordingly, the lack of scratch marks does not support the hypothesis that a tetrapod the size of the entombed Lystrosaurus juvenile constructed NMQR 3606.

Thus, the alternative hypothesis that NMQR 3606 was made by a species of another tetrapod genus needs to be considered. The attribution-by-greater-numbers hypothesis, based on the observation that Lystrosaurus is the numerically dominant genus of the LAZ, is not an infallable line of reasoning: the most common body fossils are not necessarily correctly attributable to associated trace fossils. For example, amniote eggs collected from the Mongolian Cretaceous by the American Museum of Natural History Asiatic Expeditions were originally attributed to protoceratopsian ornithischians, the most commonly encountered body fossils in the same rocks, but it was realized recently that the eggs are of theropod parentage (Norell et al., 1994). The only other burrow cast from the LAZ that is confidently associated with a body fossil is attributed to the cynodont genus Thrinaxodon (Damiani et al., 2003). The Thrinaxodon burrow cast described by those authors, which consists of living chamber and the adjoining tunnel, includes the skeleton of a well-ossified, presumably adult Thrinaxodon. This burrow cast is about one-third the diameter of a large burrow cast similar to the one described in this paper. This size difference indicates that it is highly unlikely that the primary occupant of NMQR 3606 was a Thrinaxodon. Other cynodonts are known from the LAZ, but they are approximately the same size as Thrinaxodon, and much less common. The only other dicynodont genus known from the LAZ is Myosaurus, for which burrow casts are not known. Myosaurus is a close relative of the Permian cistecephalid genera Cistecephalus and Kawingasaurus (Angielczyk, 2007; Fröbisch, 2007), which are regarded 

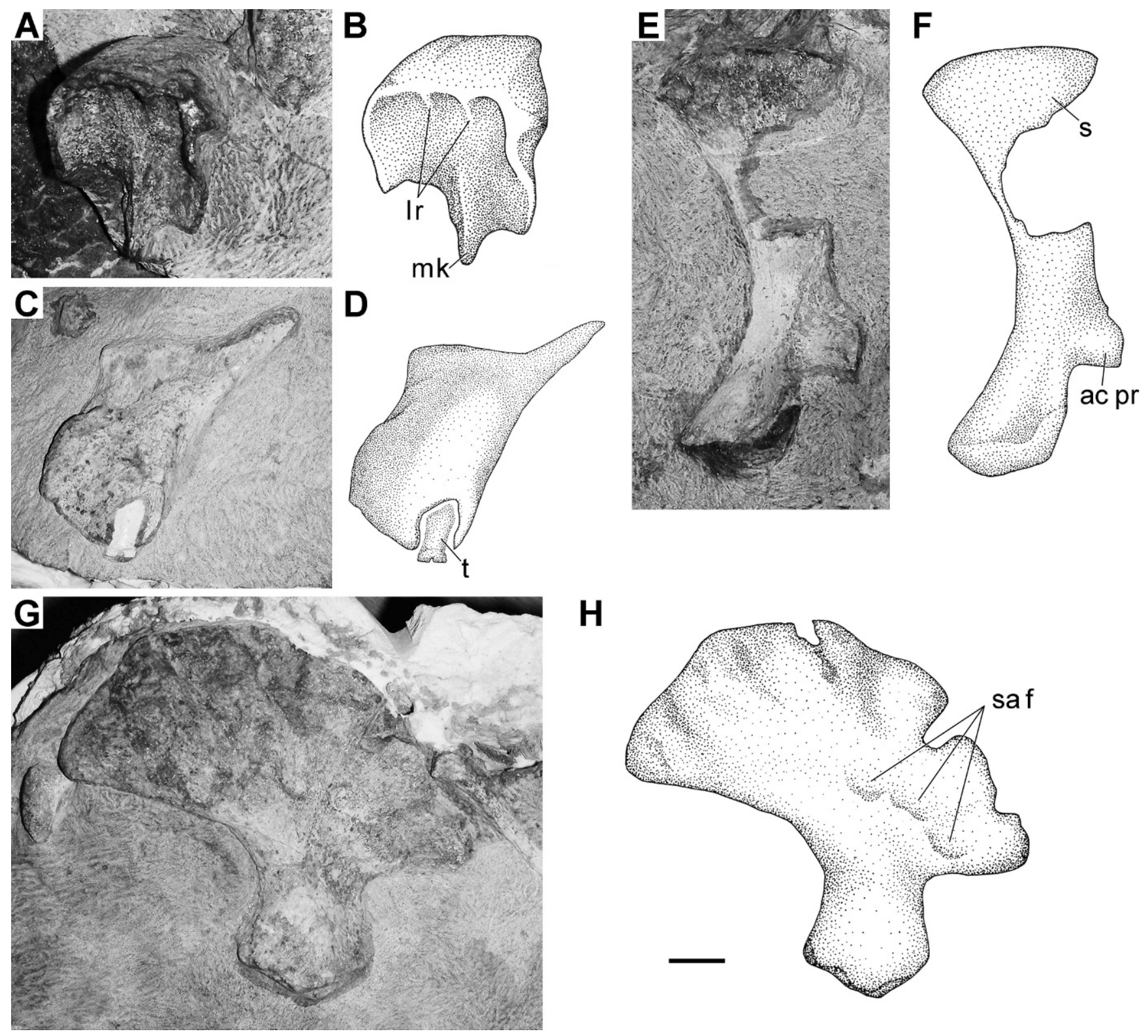

FIGURE 7-Photograph of premaxilla in ventral view (A) and interpretive drawing of same in anteroventral view (B). Photograph of left maxilla in lateral view (C) and interpretive drawing of same (D). Photograph of left scapula in medial view (E) and interpretive drawing of same (F). Photograph of right ilium in medial view (G) and interpretive drawing of same $(\mathrm{H})$. Abbreviations: ac pr, acromion process, $1 \mathrm{r}=$ lateral ridges, $\mathrm{m} \mathrm{k}=$ median keel, $\mathrm{s}=$ scapular blade, $\mathrm{sa} \mathrm{f}=\mathrm{sacral}$ rib facets, $\mathrm{t}=$ tusk. Scale bar $1 \mathrm{~cm}$.

as the dicynodont taxa most highly adapted to a fossorial mode of life (Cox, 1972; Cluver, 1978). The phylogenetic propinquity of Myosaurus to these cistecephalids suggests that it, too, was a digger. The 11 known specimens of Myosaurus, all of which are skulls (Hammer and Cosgriff, 1981), however, indicate a tetrapod that is smaller than Thrinaxodon. The only other genus of LAZ dicynodont is, therefore, clearly not the constructor of these large burrows. NMQR 3606 is much too large to have been constructed by any of the small diapsids or relatively numerous procolophonoid reptiles, none of which were larger than Thrinaxodon. The only remaining possible alternatives in the LAZ fauna are the archosauriform genus Proterosuchus and akidnognathid theriodonts of the genera Moschorhinus and Olivierosuchus. The burrowing abilities of these carnivorous taxa have yet to be assessed, however, and specimens of Proterosuchus are more rare than those of the theriodonts. Moschorhinus is by far the most common large carnivorous tetrapod of the LAZ but, surprisingly, its postcrania have yet to be described, and we can only assess its potential as a burrower by proxy. Our own work on Olivierosuchus reveals that this theriodont is now known from four specimens (Botha-Brink and Modesto, unpublished data, 2010), including the one from Barendskraal, which is also the largest (skull length of $\sim 11 \mathrm{~cm}$ ). Interestingly, the known pectoral appendicular morphology of Olivierosuchus is consistent with a burrowing habit (Brink, 1965; Botha-Brink and Modesto, unpublished data, 2010): the manual unguals are spadelike and 50\%-60\% longer than the penultimate phalanges. The Olivierosuchus individual from Barendskraal appears to be too small for NMQR 3606, but we envision that individuals of this genus could have constructed those on the smaller end $(\sim 20 \mathrm{~cm}$ diameter) of the spectrum of type $1 \mathrm{~b}$ burrows described by Groenewald (1991). If the manual morphology of Moschorhinus was similar to that of Olivierosuchus, large individuals of the former genus could have been responsible for the largest (up to $45 \mathrm{~cm}$ diameter) burrow casts documented by Groenewald (1991).

Accordingly, large-diameter, subhorizontal burrows may be the products of akidnognathids, which were the largest theriodonts of the 
LAZ. This attribution accords well with the simple, straight structure of large-diameter burrows noted by Groenewald (1991) and evident in NMQR 3606, and the general view that carnivores construct relatively straight burrows (Voorhies, 1975; Gobetz, 2006; Hembree and Hasiotis, 2008). The simple architecture of large-diameter burrows contrasts with that of the longer, coiled, large-scale Daimonelix-like burrow casts from other LAZ localities, which were attributed to Lystrosaurus by Groenewald (1991), and with the coiled Daimonelix-like burrows constructed by the Permian dicynodont Diictodon (Smith, 1987).

Further evidence that our burrow cast was not constructed by Lystrosaurus is the observation that the juvenile skeleton interred in NMQR 3606 is not preserved in the articulated, curled-up attitude of documented therapsid occupants of Permian and Triassic burrows (e.g., Smith 1987; Damiani et al., 2003). The juvenile Lystrosaurus skeleton of NMQR 3606 is disarticulated and incomplete and, thus, it is possible that the skeleton represents the remains of a carcass that was dragged into the burrow by a carnivorous tetrapod. The relatively pristine state of all elements but one, however, might argue against the interpretation that the juvenile dicynodont was a prey item or a scavenged carcass. Skeletons that have been interpreted as having been preyed upon, or scavenged by, carnivorous tetrapods exhibit clear and unmistakable tooth marks (Fiorillo, 1991; Erickson and Olson, 1996; Reisz and Tsuji, 2006). Multiple tooth marks may be present on a single bone (Fowler and Sullivan, 2006) or individual tooth marks are present on several elements (Reisz and Tsuji, 2006). The single, possible exception in NMQR 3606 is the damaged scapula. The roughly polygonal outline of the emargination in the scapula, however, does not seem to be consistent with a tooth puncture or a bite mark from a jaw with several teeth. Such akidnognathids as Moschorhinus and Olivierosuchus possessed conspicuous canines and incisors (Brink, 1965), which one might expect to have left a mark on at least one of the preserved elements if the Lystrosaurus skeleton represents the remains of a meal. Moschorhinus and Olivierosuchus, however, are characterized also by a reduced number of postcanine teeth (3-4 postcanines; Brink, 1965; Durand, 1991), and this suggests that the postcanine teeth of these akidnognathids played a minor role in food processing. If so, akidnognathids might not be expected to leave tooth marks on the bones of their prey, particularly if their feeding strategy was to use their larger and anteriorly placed teeth, the canines and the incisors, to nip off limbs and chunks from the torso of their prey into pieces that were small enough to swallow whole, which could have included whole bones.

We feel that the available evidence favors the hypothesis that the juvenile dicynodont was a larded prey item, and that the burrow maker was a carnivorous member of the LAZ fauna. Both the partial skeleton and the burrow might have been abandoned, perhaps temporarily, by the tracemaker, with the skeleton disturbed subsequently, possibly when the original occupant returned to its burrow, or perhaps in an exploratory investigation by another tetrapod. Pursuant to this hypothesis, the numerical dominance of Lystrosaurus individuals in the LAZ fauna accords well with the idea that species of this genus would be the most common prey in that fauna. Thus, the discovery of Lystrosaurus skeletal remains should be anticipated in at least some burrow casts attributable to coeval carnivores.

\section{CONCLUSIONS}

A burrow cast containing skeletal contents is described from the lowermost Triassic strata of the Palingkloof Member, Balfour Formation in the Karoo Basin, South Africa, strata that are regarded as forming the base of the Lystrosaurus Assemblage Zone. The skeletal contents comprise the partial, disarticulated skeleton of a single tetrapod that can be assigned with confidence to the dicynodont therapsid genus Lystrosaurus. The burrow cast is most similar to those described from higher sections in the LAZ comprising Groenewald's
(1991) type 1b burrow casts. Thus, the specimen described here represents the oldest large-diameter burrow cast in the LAZ. The Lystrosaurus skeleton is the first such remains to be described in detail from a large burrow cast collected from the LAZ, and at first glance lends some support to previous work that tentatively attributed largediameter burrow casts to Lystrosaurus. The partial Lystrosaurus skeleton does not exhibit obvious signs of scavenging, apart from inexplicable damage to a single appendicular element, and disarticulation and the incomplete nature of the Lystrosaurus skeleton is suggestive of post-mortem disturbance. Furthermore, the burrow appears to be too large to have been constructed by the interred Lystrosaurus individual. Accordingly, we favor the alternative interpretation that a carnivorous member of the LAZ constructed the burrow, and that the Lystrosaurus skeleton represents a larded prey item. Suitable candidates for the burrow maker can be found among akidnognathid theriodonts, of which numerous specimens exist in museum collections and exhibit a range in size that is compatible with the tracemakers of large-diameter, subhorizontal burrows of the LAZ. Support for our preferred hypothesis is the relatively simple design of the burrow cast, which is superficially similar in construction, but not in size, to burrow casts constructed by the cynodont genus Thrinaxodon, and our own observations on the appendicular morphology of the akidnognathid Olivierosuchus, which we believe is consonant with burrowing abilities, and is a suitable proxy for its larger relative Moschorhinus. Ongoing fieldwork in the LAZ has yielded further large burrow casts (Smith and Botha-Brink, 2009). We expect that any skeletal remains found within these structures will be invaluable towards testing the hypothesis that large-diameter, subhorizontal burrow casts of the LAZ are attributable to predators for whom members of the genus Lystrosaurus were principal prey.

\section{ACKNOWLEDGMENTS}

We thank R. and J. Rogers, Middelburg District, for permission to prospect on Barendskraal, and J. Nyaphuli (NM) for assistance in the field and for his monumental effort in preparing NMQR 3606. We also acknowledge S. Stuurman and J. Mohoi (NM) and D.K. Zelenitsky (University of Calgary) for help in the field, J. Cooper (Cape Breton University) for the drawings that appear in Figure 7, E. Butler (NM) for bibliographic assistance, J. Neveling for permission to use the image that appears in Figure 3, and J. Fröbisch and an anonymous reviewer for their comments on the manuscript. Our research is funded by a discovery grant (no. 288126-07) from the Natural Sciences and Engineering Research Council (NSERC) of Canada and a Canadian Foundation for Innovation New Opportunities Fund Award to S.P.M., and a grant (GUN 2061695) from the National Research Foundation of South Africa to J.B.B.

\section{REFERENCES}

Abdala, F.A., Cisneros, J.C., and Smith, R.M.H., 2006, Faunal aggregation in the Early Triassic: Earliest evidence of shelter-sharing behavior among tetrapods?: PALAIOS, v. 21, p. 507-512, doi: 10.2110/palo.2005.P06-001R.

AngielczYK, K.D., 2007, New specimens of the Tanzanian dicynodont "Cryptocynodon" parringtoni von Huene, 1942 (Therapsida, Anomodontia), with an expanded analysis of Permian dicynodont phylogeny: Journal of Vertebrate Paleontology, v. 27, p. 116-131

Botha, J., and Sмiтh, R.M.H., 2007, Lystrosaurus species composition across the Permo-Triassic boundary in the Karoo Basin of South Africa: Lethaia, v. 40, p. 125-137, doi: 10.1111/j.1502-3931.2007.00011.x.

Brink, A.S., 1965, A new ictidosuchid (Scaloposauria) from the Lystrosaurus-Zone: Palaeontologia Africana, v. 9, p. 129-138.

Cluver, M.A., 1971, The cranial morphology of the dicynodont genus Lystrosaurus: Annals of the South African Museum, v. 56, p. 155-274.

Cluver, M.A., 1978, The skeleton of the mammal-like reptile Cistecephalus with evidence for a fossorial mode of life: Annals of the South African Museum, v. 76, p. 213-246. 
Cox, C.B., 1972, A new digging dicynodont from the Upper Permian of Tanzania, in Joysey, K.A., and Kemp, T.S., eds., Studies in Vertebrate Evolution: Oliver and Boyd, Edinburgh, p. 173-189.

Damiani, R., Modesto, S., Yates, A., and Neveling, J., 2003, Earliest evidence of cynodont burrowing: Proceedings of the Royal Society B, v. 270, p. 1747-1752, doi: $10.1098 / \mathrm{rspb} .2003 .2427$.

Damiani, R., Neveling, J., Modesto, S., and Yates, A., 2004, Barendskraal, a diverse amniote locality from the Lystrosaurus Assemblage Zone, Early Triassic of South Africa: Palaeontologia Africana, v. 39, p. 53-62.

Durand, F., 1991, A revised description of the skull of Moschorhinus (Therapsida, Therocephalia): Annals of the South African Museum, v. 99, p. 381-413.

Erickson, G.M., and Olson, K.H., 1996, Bite marks attributable to Tyrannosaurus rex: Preliminary description and implications: Journal of Vertebrate Paleontology, v. 16 , p. 175-178.

FioriLlo, A.R., 1991, Prey bone utilization by predatory dinosaurs: Palaeogeography, Palaeoclimatology, Palaeoecology, v. 88, p. 157-166.

Fowler, D.W., and Sullivan, R.M., 2006, A ceratopsid pelvis with toothmarks from the Upper Cretaceous Kirtland Formation, New Mexico: Evidence of late Campanian tyrannosaurid feeding behavior, in Lucas, S.G., and Sullivan, R.M., eds., Late Cretaceous Vertebrates from the Western Interior: New Mexico Museum of Natural History and Science Bulletin, v. 35, p. 127-130.

Frey, R.W., Pemberton, S.G., and Fagerstrom, J.A., 1984, Morphological, ethological, and environmental significance of the ichnogenera Scoyenia and Ancorichnus: Journal of Paleontology, v. 58, p. 511-528.

FröBISCH, J., 2007, The cranial anatomy of Kombuisia frerensis Hotton (Synapsida, Dicynodontia) and a new phylogeny of anomodont therapsids: Zoological Journal of the Linnean Society, v. 150, p. 117-144.

Gastaldo, R.A., and Rolerson, M.Y., 2008, Katbergia gen. nov., a new trace fossil from Upper Permian and Lower Triassic rocks of the Karoo Basin: Implications for palaeoenvironmental conditions at the P/Tr extinction event: Palaeontology, v. 51, p. 215-229, doi: 10.1111/j.1475-4983.2007.00743.x.

Gobetz, K.E., 2006, Possible burrows of mylagulids (Rodentia: Aplodontoidea: Mylagulidae) from the late Miocene (Barstovian) Pawnee Creek Formation of northeastern Colorado: Palaeogeography, Palaeoclimatology, Palaeoecology, v. 237, p. 119-136, doi: 10.1016/j.palaeo.2005.09.004.

Groenewald, G.H., 1991, Burrow casts from the Lystrosaurus-Procolophon Assemblage-zone, Karoo Sequence, South Africa: Koedoe, v. 34, p. 13-22.

Groenewald, G.H., and Kitching, J.W., 1995, Biostratigraphy of the Lystrosaurus Assemblage Zone, in Rubidge, B.S., ed., Biostratigraphy of the Beaufort Group (Karoo Supergroup): Biostratigraphic Series No. 1, Council for Geoscience, Pretoria, p. 35-39.

Groenewald, G.H., Welman, J., and MacEachern, J.A., 2001, Vertebrate burrow complexes from the Early Triassic Cynognathus Assemblage Zone (Driekoppen Formation, Beaufort Group) of the Karoo Basin, South Africa: PALAIOS, v. 16, p. $148-160$

Hammer, W.R., and Cosgriff, J.W., 1981, Myosaurus gracilis, an anomodont reptile from the Lower Triassic of Antarctica and South Africa: Journal of Paleontology, v. 55 , p. $410-424$.

Hasiotis, S.T., Wellner, R.W., Martin, A.J., and Demko, T.M., 2004, Vertebrate burrows from Triassic and Jurassic continental deposits of North America and Antarctica: Their paleoenvironmental and paleoecological significance: Ichnos, v. 11, p. $103-124$.

Hembree, D.I., and Hasiotis, S.T., 2008, Miocene vertebrate and invertebrate burrows defining compound paleosols in the Pawnee Creek Formation, Colorado,
U.S.A.: Palaeogeography, Palaeoclimatology, Palaeoecology, v. 270, p. 349-365, doi: 10.1016/j.palaeo.2008.07.019.

Hoogland, J.L., 1995, The Black-tailed Prairie Dog: Social Life of a Burrowing Mammal: University of Chicago Press, Chicago, 557 p.

Kerr, G.D., and Bull, C.M., 2004, Microhabitat use by the scincid lizard Tiliqua rugosa: Exploiting natural temperature gradients beneath plant canopies: Journal of Herpetology, v. 38, p. 536-545, doi: 10.1670/82-04A.

KInG, G.M., and Cluver, M.A., 1991, The aquatic Lystrosaurus: An alternative lifestyle, Historical Biology, v. 4, p. 323-341.

Kinlaw, A., 1999, A review of burrowing by semi-fossorial vertebrates in arid environments: Journal of Arid Environments, v. 41, p. 127-145, doi: 10.1006/ jare.1998.0476.

Norell, M.A., Clark, J.M., Dashzeveg, D., Barsbold, R., Chiappe, L.M., Davidson, A.R., McKenna, M.C., Perle, A., and Novacek, M.J., 1994, A theropod dinosaur embryo and the affinities of the Flaming Cliffs dinosaur eggs: Science, v. 266, p. 779-782.

RAY, S., 2006, Functional and evolutionary aspects of the postcranial anatomy of dicynodonts (Synapsida, Therapsida): Palaeontology, v. 49, p. 1263-1286, doi: 10.1111/j.1475-4983.2006.00597.x.

Reisz, R. R., and Tsusi, L. A., 2006, An articulated skeleton of Varanops with bite marks: The oldest known evidence of scavenging among terrestrial vertebrates: Journal of Vertebrate Paleontology, v. 24, p. 1021-1023.

Retallack, G.J., Smith, R.M.H., and Ward, P.D., 2003, Vertebrate extinction across Permian-Triassic boundary in Karoo Basin, South Africa: Geological Society of America, Bulletin, v. 115, p. 1133-1152, doi: 10.1130/B25215.1.

Sмiтh, R.M.H., 1987, Helical burrow casts of therapsid origin from the Beaufort Group (Permian) of South Africa: Palaeogeography, Palaeoclimatology, Palaeoecology, v. 60 , p. 155-170.

Sмiтн, R.M.H., and Bотна, J., 2005, The recovery of terrestrial vertebrate diversity in the South African Karoo Basin after the end-Permian extinction: Comptes Rendus Palevol, v. 4, p. 555-568, doi: 10.1016/j.crpv.2005.07.005.

Smith, R., and Botha-Brink, J., 2009, Burrowing as a survival strategy in the earliest Triassic Karoo Basin: Journal of Vertebrate Paleontology, v. 29, suppl. to no. 3, p. $183 \mathrm{~A}$.

TABER, F.W., 1945, Contribution on the life history and ecology of the nine-banded armadillo: Journal of Mammalogy, v. 26, p. 211-226.

Voorhies, M.R., 1975, Vertebrate burrows, in Frey, R.W., ed., The Study of Trace Fossils: Springer, New York, p. 325-350.

Watson, D.M.S., 1912, The skeleton of Lystrosaurus: Records of the Albany Museum, v. 2, p. 287-299.

Weigelt, J., 1989, Recent Vertebrate Carcasses and their Paleobiological Implications: University of Chicago Press, Chicago, 188 p. [English translation of original 1927 publication.]

White, C.R., 2005, The allometry of burrow geometry: Journal of Zoology, London, v. 265 , p. $395-403$.

White, A.M., and Cameron, E. Z., 2009, Communal nesting is unrelated to burrow availability in the common warthog: Animal Behaviour, v. 77, p. 87-94, doi: 10.1016/j.anbehav.2008.08.030.

Witz, B.W., Wilson, D.S., and Palmer, M.D., 1991, Distribution of Gopherus polyphemus and its vertebrate symbionts: American Midland Naturalist, v. 126, p. $152-158$.

ACCEPTED JANUARY 8, 2010 